\title{
Evaluation of left ventricular systolic function by Myocardial Deformation Imaging in asymptomatic HIV patients
}

\author{
Kunjang Sherpa', Ram Kishor Sah', Arun Maskey², Rabi Malla², Deewakar Sharma², Sujeeb \\ Rajbhandari², Man Bahadur KC ${ }^{2}$, Rikesh Tamrakar' ${ }^{2}$, Sushil Shakya ${ }^{3}$, Birat KrishnaTimilsina', \\ Anish Hirachan', Prabha Chapagain Koirala', Ajay Adhikari' ${ }^{1}$, Shaneez Nazmy ${ }^{1}$
}

${ }^{1}$ Department of Cardiology, National Academy Of Medical Sciences, Bir hospital, Kathmandu, Nepal

${ }^{2}$ Department of Cardiology, Sahid Gangalal National Heart center, Kathmandu, Nepal

${ }^{3}$ Department of General practice and Emergency medicine / ART clinic, Bir Hospital, Nepal

Corresponding Author: Kunjang Sherpa,

Department of Cardiology, National Academy of Medical Sciences,

Bir hospital, Kathmandu, Nepal

Email: sherpakunjang7@gmail.com

ORCID ID NO: 0000-0003-1136-6983

Cite this article as: Sherpa K., Sah R. K., Maskey A., et al. Evaluation of left ventricular systolic function by Myocardial Deformation Imaging in asymptomatic HIV patients. Nepalese Heart Journal 2019; Vol 16 (2), 11-15

Submission date: $13^{\text {th }}$ June 2019

Accepted date: $31^{\text {st }}$ August 2019

Abstract

Background and Aims: Despite improvements in clinical care, evidence from both industrialized and developing countries indicates that the prevalence of subclinical cardiac dysfunction in individuals with well-controlled HIV infection may approach $50 \%$ and represent a newly recognized comorbid condition. The aim of our study was to reveal abnormalities in cardiac function using conventional transthoracic echocardiography and left ventricular strain imaging in HIV infected patients without cardiovascular disease.

Methods: This was a hospital based, single center descriptive cross-sectional comparative study conducted in National Academy of Medical Sciences (NAMS), Bir Hospital which included HIV patients with baseline examination including a patient medical history, clinical examination, baseline CD4 count, viral load and a standardized transthoracic echocardiography and strain imaging examination and the findings were compared among age and sex frequency matched healthy adult population. Results: Our study enrolled 142 patients out of which 95 HIV positive patients (mean age $36.7 \pm 9.2$ years with $58 \%$ female) and 47 healthy control (mean age $33.7 \pm 8$ years with $57.4 \%$ female). The median duration of HIV diagnosis was 7 years (IQR 2, 10) and median CD4 count was 464 cells $/ \mathrm{mm}^{3}$ (IQR 259,750). There was no significant difference in conventional echocardiographic parameters between two groups except for transmitral E velocity that was lower in HIV group ( $p$ value of 0.001). The HIV population has lower mean global longitudinal strain (GLS) value of $-19.92 \% \pm 2.54$ SD compared to the healthy control population with mean of $-21.39 \% \pm 1.54 \mathrm{SD}$ ( $\mathrm{p}$ value of 0.001 ) and patients with CD4 count less than 300 cell/ $\mathrm{mm}^{3}$ had GLS value significantly lower than $-18 \%$ ( $\mathrm{p}$ value of 0.05 ).

Conclusion: HIV infected population without established cardiovascular disease have subclinical left ventricular dysfunction revealed by GLS imaging technique.

Keywords: Global Longitudinal strain, HIV Infection, LV systolic dysfunction.

DOI: https://doi.org/10.3126/njh.v16i2.26310

\section{Introduction}

Despite improvements in clinical care, evidence from both industrialized and developing countries indicates that the prevalence of subclinical cardiac dysfunction in individuals with wellcontrolled HIV infection may approach $50 \%$ and represent a newly recognized comorbid condition ${ }^{1,2}$. Many studies reported a strong association between human immunodeficiency virus (HIV) infection and cardiac abnormalities, which are closely associated with high morbidity and mortality 3,4 . Cardiovascular manifestations have two clinical patterns: $6-7 \%$ of HIV-infected patients have significant

@ Nepalese Heart Journal. Nepalese Heart Journal retain copyright and works is simultaneously licensed under Creative Commons Attribution License CC - By 4.0 that allows others to share the work with an acknowledge of the work's authorship and initial publication in this journal

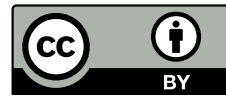


cardiac disease while the remainder is asymptomatic. Among asymptomatic patients, $8-10 \%$ develop symptomatic heart disease over a two- to five-year period, which constitutes an independent predictor of mortality ${ }^{5,6}$.

HIV infection itself is accompanied by subclinical left ventricular systolic dysfunction, which is not apparent to standard echocardiography, which can be unmasked through using sensitive echocardiographic techniques. Global longitudinal strain (GLS) echocardiographic imaging, allows for more direct assessment of myocardial muscle shortening and lengthening throughout cardiac cycle by assessing myocardial strain that can unmask left ventricular dysfunction in asymptomatic patients ${ }^{7,8}$. As heart failure is often recognized late in HIV infected patients, early detection of left ventricular function is crucial.

There are very few studies done around the globe studying GLS imaging showing that it can unmask LV systolic dysfunction in asymptomatic HIV patients not apparent to standard transthoracic echocardiography and there are no any studies done in our part of the world. Hence, the present study aim to examine population of asymptomatic HIV-infected patients with GLS imaging for early detection of left ventricular systolic dysfunction.

\section{Methods}

The study was a hospital based, single center descriptive crosssectional comparative study conducted for 6 months (December 2018 to May 2019) in National Academy of Medical Sciences (NAMS), Bir hospital which included HIV patients visiting the anti-retroviral therapy (ART) clinic of Bir hospital with the baseline examination including a patient history, medication treatment, baseline CD4 count and viral load. Furthermore, noninvasive cardiac test such as heart rate, blood pressure, and a standardized transthoracic echocardiography and strain imaging examination was a part of the study protocol. To compare the findings, we also included age and sex frequency matched healthy adult population. We recruited 95 HIV patients by sample size calculation based on estimated prevalence of systolic cardiac dysfunction of $34.3 \%$ by a large, prospective multicenter HIVheart study ${ }^{1}$. The inclusion criteria were patient with HIV -Infection and age $>18$ years and the exclusion criteria were patients with pre-existing cardiac disease, pregnant women, patients with diabetes, hypertension, dyslipidemia, renal disease, liver disease, Centers for Disease Control and Prevention (CDC) Class C patients and refusal to give consent. We also included control group in $1: 2$ case ratio with total of 47 healthy adults with age and sex frequency matched group to compare our findings between HIV vs. Non- HIV patients. Formal permission for the study was taken from the institutional review board of the NAMS and informed consent was taken from the study population.

Transthoracic echocardiography was performed with a commercially available imaging system with PHILLIP Affiniti 50c Echocardiography machine using a $2.5 \mathrm{MHz}$ phased array transducer. Cardiac dimension and cardiac function was measured according to the recommendations of the American Society of Echocardiography'. Global longitudinal strain (GLS) was calculated by the mean longitudinal strain of the six walls (basal, mid and apical segments) in apical view. The software automatically displayed an epicardial tracing to include the entire myocardial width, and was later adjusted manually for optimal tracking. GLS value less than $-18 \%$ was considered abnormal for detecting LV systolic dysfunction as a value above $-20 \%$ with a standard deviation of $\sim \pm 2 \%$, the value cited by the American Society of Echocardiography, is likely to be normal ${ }^{10}$. Intraobserver reproducibility was determined by an echocardiographer's own analysis and inter-observer reproducibility was determined by the analyses of two echocardiographers for strain imaging after 2 weeks on stored offline images of 15 random study population.

Statistical analysis

All data were entered into an electronic spreadsheet (Microsoft Excel, Redmond) and the statistical analysis was done using the SPSS version 20 software (SPSS INC, Chicago, III). Categorical variables were analyzed as percentage, continuous variable with normal distribution presented as mean $\pm \mathrm{SD}$ and continuous variable with skewed distribution presented as median and interquartile range (IQR). After processing of all available information, statistical analysis of their significance was done. Dichotomous variable were compared using Chi-Square test or Fischer's exact test, as appropriate and independent $t$ test for means of continuous variable. 'P' value of less than 0.05 was considered to be significant. Coefficient of variation analysis were performed for intra- and inter-observer reproducibility of strain imaging echocardiography

\section{Results}

Our study enrolled 142 patients out of which 95 were HIV positive patients with mean age $36.7 \pm 9.2,58 \%$ female and 47 healthy control with mean age $33.7 \pm 8$, with $57.4 \%$ female population. The clinical characteristics of the HIV-infected population are presented in table 1 and comparison with control group are presented in table 2. The median duration of HIV diagnosis was 7 years $($ IQR 2,10$)$ and median CD4 count was 464 cells $/ \mathrm{mm}^{3}$ (IQR 259,750). Among the HIV patients $71.6 \%$ had viral copies $<50$ copies $/ \mathrm{ml}$ and $87.4 \%$ were taking antiretroviral therapy (ARV). The median duration of ARV duration was 5 years (IQR 1, 10). With respect to age, sex and blood pressure there were no significant differences among the two groups, however the HIV group has mean BMI of $22.5 \pm 2.87$ significantly lower than control group (BMI $23.79 \pm 3.13$ ) ( $\mathrm{p}$ value of 0.02 ).

Table1: Baseline Clinical Characteristics of the HIV-Infected Population

\begin{tabular}{|c|c|}
\hline Variable & HIV group $(n=95)$ \\
\hline Age in years $($ mean $\pm \mathrm{SD})$ & $36.7 \pm 9.2$ \\
\hline Female (N/\%) & $55(58 \%)$ \\
\hline $\begin{array}{l}\text { BMI (weight in } \mathrm{kg} / \text { height in } \mathrm{mm}^{2} \text { ) } \\
(\mathrm{mean} \pm \mathrm{SD})\end{array}$ & $22.5 \pm 2.87$ \\
\hline Systolic $\mathrm{BP}$ in $\mathrm{mmHg}($ mean $\pm \mathrm{SD})$ & $114 \pm 11$ \\
\hline Diastolic BP in $\mathrm{mmHg}($ mean $\pm \mathrm{SD})$ & $73.2 \pm 6.7$ \\
\hline $\begin{array}{l}\text { CD } 4 \text { count }\left(\text { cells } / \mathrm{mm}^{3}\right) \\
{[\text { Median }(\mathrm{IQR})]}\end{array}$ & 464 (IQR 259,750) \\
\hline Viral load $(<50$ Copies $/ \mathrm{ml})$ & $68(71.6 \%)$ \\
\hline $\begin{array}{l}\text { Duration of HIV diagnosis (years) } \\
\text { [Median (IQR)] }\end{array}$ & 7 (IQR 2,10) \\
\hline ARV use (N/\%) & $83(87.4 \%)$ \\
\hline $\begin{array}{l}\text { Duration of ART therapy (years) } \\
\text { [Median (IQR)] }\end{array}$ & $5(\mathrm{IQR} 1,10)$ \\
\hline
\end{tabular}

The conventional and strain echocardiographic parameters of HIV infected population and healthy control population are shown in table 3 and 4 respectively. There was no significant differences in conventional echocardiographic parameters between HIV population and healthy population except for transmittal $\mathrm{E}$ velocity which were 
significantly lower in HIV group ( $\mathrm{p}$ value of 0.001 ).

In strain imaging, the asymptomatic HIV population with normal Left ventricular ejection fraction (LVEF) have significantly lower mean GLS value of $-19.92 \% \pm 2.54 \mathrm{SD}$ compared to the healthy control population with mean GLS value of $-21.39 \% \pm 1.54$ SD (p value of 0.001$)$.

In HIV patients, the relationship of GLS value to different baseline CD4 count and HIV viral load, duration of HIV diagnosis, HAART (highly active antiretroviral treatment) therapy and HAART

Table 2: Clinical Characteristics of HIV Infected Population and Control Group

\begin{tabular}{|c|c|c|c|}
\hline Variable & $\begin{array}{l}\text { HIV group } \\
(n=95)\end{array}$ & $\begin{array}{l}\text { Control group } \\
(n=47)\end{array}$ & p value \\
\hline $\begin{array}{l}\text { Age in years (mean } \\
\pm \mathrm{SD})\end{array}$ & $36.7 \pm 9.2$ & $33.7 \pm 8$ & $0.062^{\mathrm{a}}$ \\
\hline Female (N/\%) & $55(58 \%)$ & $27(57.4 \%)$ & $0.959^{\mathrm{b}}$ \\
\hline $\begin{array}{l}\text { BMI (weight in } \mathrm{kg} \\
\left.\text { /height in } \mathrm{mm}^{2}\right) \\
(\text { mean } \pm \mathrm{SD})\end{array}$ & $22.5 \pm 2.87$ & $23.79 \pm 3.13$ & $0.02^{\mathrm{a}}$ \\
\hline $\begin{array}{l}\text { Systolic BP in } \\
\text { mmHg (mean } \pm \\
\text { SD) }\end{array}$ & $114 \pm 11$ & $113 \pm 10$ & $0.69^{a}$ \\
\hline $\begin{array}{l}\text { Diastolic BP in } \\
\text { mmHg (mean } \pm \\
\text { SD) }\end{array}$ & $73.2 \pm 6.7$ & $72.92 \pm 7.1$ & $0.85^{\mathrm{a}}$ \\
\hline
\end{tabular}

${ }^{\mathrm{a}} \mathrm{p}$ value from $\mathrm{t}$ test, ${ }^{\mathrm{b}} \mathrm{P}$-value $\mathrm{f}$ from $\chi^{2}$ test

Table 3: Conventional echocardiographic parameters of the HIVinfected population and the control group.

\begin{tabular}{|c|c|c|c|}
\hline $\begin{array}{l}\text { Echo } \\
\text { Parameters }\end{array}$ & $\begin{array}{l}\text { HIV group } \\
(\text { Mean } \pm \text { SD })\end{array}$ & $\begin{array}{l}\text { Control } \\
(\text { Mean } \pm \text { SD })\end{array}$ & P-value \\
\hline LVEDD (mm) & $4.39 \pm 0.447$ & $4.47 \pm 0.438$ & $0.291^{\mathrm{a}}$ \\
\hline LVEDS (mm) & $2.84 \pm 0.45$ & $2.96 \pm 0.422$ & $0.137^{\mathrm{a}}$ \\
\hline IVS (mm) & $0.978 \pm 0.16$ & $0.95 \pm 0.121$ & $0.251^{\mathrm{a}}$ \\
\hline PW (mm) & $0.80 \pm 0.13$ & $0.76 \pm 0.12$ & $0.07^{\mathrm{a}}$ \\
\hline $\begin{array}{l}\text { LV mass index } \\
\left(\mathrm{gm} / \mathrm{m}^{2}\right)\end{array}$ & $117 \pm 31$ & $115 \pm 21.6$ & $0.81^{\mathrm{a}}$ \\
\hline FS $(\%)$ & $33 \pm 4.24$ & $34 \pm 2.95$ & $0.604^{\mathrm{a}}$ \\
\hline $\mathrm{EF}(\%)$ & $63.12 \pm 4.3$ & $63.3 \pm 2.9$ & $0.748^{\mathrm{a}}$ \\
\hline $\operatorname{Emax}(\mathrm{cm} / \mathrm{s})$ & $73.6 \pm 16.3$ & $89.09 \pm 19.04$ & $0.001^{\mathrm{a}}$ \\
\hline $\operatorname{Amax}(\mathrm{cm} / \mathrm{s})$ & $66.04 \pm 16.32$ & $65.7 \pm 14.85$ & $0.941^{\mathrm{a}}$ \\
\hline Average E/e' & $7.39 \pm 1.86$ & $8.06 \pm 1.86$ & $0.051^{\mathrm{a}}$ \\
\hline $\begin{array}{l}\text { LA volume }\left(\mathrm{m}^{1 /}\right. \\
\left.\mathrm{m}^{2}\right)\end{array}$ & $18.38 \pm 3.81$ & $17 \pm 2.7$ & $0.234^{\mathrm{a}}$ \\
\hline $\begin{array}{l}\text { RV basal } \\
\text { dimension }(\mathrm{mm})\end{array}$ & $2.7 \pm 0.41$ & $2.9 \pm 0.34$ & $0.06^{\mathrm{a}}$ \\
\hline IVC & $1.42 \pm 0.21$ & $1.45 \pm 0.11$ & $0.115^{\mathrm{a}}$ \\
\hline TAPSE (cm) & $2.07 \pm 1.3$ & $1.88 \pm 0.14$ & $0.342^{\mathrm{a}}$ \\
\hline $\begin{array}{l}\text { Lateral S' } \\
(\mathrm{cm} / \mathrm{s})\end{array}$ & $12.5 \pm 2.1$ & $13.4 \pm 1.2$ & $0.370^{\mathrm{a}}$ \\
\hline$p$ value from $t$ test & & & \\
\hline
\end{tabular}

Table 4: Strain Parameters in the HIV-Infected Population and the Control Group

\begin{tabular}{|c|c|c|c|}
\hline & HIV group & Control & p-value \\
\hline $\begin{array}{l}\text { GLS in } \% \\
(\text { mean } \pm \mathrm{SD})\end{array}$ & $\begin{array}{l}-19.92 \\
\pm 2.54\end{array}$ & $-21.39 \pm 1.54$ & $0.001^{\mathrm{a}}$ \\
\hline
\end{tabular}

Table 5: Relationship of LV Function with GLS to Baseline CD4 Count.

\begin{tabular}{|c|c|c|c|}
\hline \multirow[t]{2}{*}{$\begin{array}{l}\text { CD4 count (cells/ } \\
\text { mm }^{3} \text { ) }\end{array}$} & \multicolumn{2}{|c|}{$\begin{array}{l}\text { Global Longitudinal strain } \\
\text { (GLS) }\end{array}$} & \multirow[t]{2}{*}{ p value } \\
\hline & $<-18 \%$ & $\geq-18 \%$ & \\
\hline $\begin{array}{l}\mathrm{CD} 4<300 \\
(\mathrm{n}=25) \mathrm{N}(\%)^{*}\end{array}$ & $8(32 \%)$ & $17(68 \%)$ & \multirow[b]{2}{*}{$0.05^{\mathrm{a}}$} \\
\hline $\begin{array}{l}\text { CD4>300 }(n=70) \\
N(\%)^{*}\end{array}$ & $10(14.2 \%)$ & $60(85.8 \%)$ & \\
\hline $\begin{array}{l}\mathrm{CD} 4<500(\mathrm{n}=49) \\
\mathrm{N}(\%)^{*}\end{array}$ & $12(24.5 \%)$ & $37(75.5 \%)$ & \multirow[b]{2}{*}{$0.155^{\mathrm{a}}$} \\
\hline $\begin{array}{l}\mathrm{CD} 4>500(\mathrm{n}=46) \\
\mathrm{N}(\%)^{*}\end{array}$ & $6(13.1 \%)$ & $40(86.9 \%)$ & \\
\hline
\end{tabular}

*N $(\%)$ represents number and percentage within row, ${ }^{a} \mathrm{p}$ value by $\chi^{2}$ test

Table 6: Relationship of LV Function with GLS with Baseline HIV Viral Load, Duration of HIV Diagnosis, HAART Therapy and HAART Therapy Duration

\begin{tabular}{|c|c|c|c|}
\hline \multirow[t]{2}{*}{$\begin{array}{l}\text { Clinical } \\
\text { Parameters }\end{array}$} & \multicolumn{2}{|c|}{$\begin{array}{l}\text { Global longitudinal } \\
\text { Strain (GLS) }\end{array}$} & \multirow[t]{2}{*}{ P-value } \\
\hline & $<-18 \%$ & $\geq-18 \%$ & \\
\hline $\begin{array}{l}\text { HIV viral load }(\mathrm{N} / \%)^{*} \\
\text { Undetectable }(<50 \text { copies } / \mathrm{ml}) \\
(\mathrm{n}=68)\end{array}$ & $\begin{array}{l}10 \\
(14.8 \%)\end{array}$ & $58(85.2 \%)$ & \multirow[t]{2}{*}{$0.134^{\mathrm{a}}$} \\
\hline $\begin{array}{l}\text { Detectable }(>50 \text { copies } / \mathrm{ml}) \\
(n=9)\end{array}$ & $4(44.4 \%)$ & $5(55.6 \%)$ & \\
\hline $\begin{array}{l}\text { Duration of HIV diagnosis } \\
\text { in years }(\mathrm{N} / \%) \\
<1(\mathrm{n}=19)\end{array}$ & $6(31.5 \%)$ & $13(68.5 \%)$ & \multirow{4}{*}{$0.179^{\mathrm{a}}$} \\
\hline 1 to $5(n=18)$ & $4(22.2 \%)$ & $14(77.8 \%)$ & \\
\hline 5 to $10(n=35)$ & $3(8.5 \%)$ & $32(91.5 \%)$ & \\
\hline$>10 \quad(n=23)$ & $5(21.8 \%)$ & $18(78.2 \%)$ & \\
\hline \multicolumn{4}{|l|}{ HAART therapy (N/\%) } \\
\hline Yes $(n=83)$ & $\begin{array}{l}14 \\
(16.8 \%)\end{array}$ & $69(83.2 \%)$ & \multirow[t]{2}{*}{$0.174^{\mathrm{a}}$} \\
\hline No $(n=12)$ & $4(33.3 \%)$ & $8(66.7 \%)$ & \\
\hline
\end{tabular}

$\begin{array}{llll}\begin{array}{l}\text { Duration Of HAART therapy } \\ \text { in year }(\mathrm{N} / \%)\end{array} & & & \\ <1(\mathrm{n}=14) & 3(21.4 \%) & 11(78.6 \%) & \\ 1 \text { to } 5(\mathrm{n}=27) & 6(22.2) & 21(77.8 \%) & 0.356^{\mathrm{a}} \\ 5 \text { to } 10(\mathrm{n}=28) & 2(7.1 \%) & 26(92.9 \%) & \\ >10(\mathrm{n}=15) & 4(26.6 \%) & 11(73.4 \%) & \end{array}$

* N(\%) represents number and percentage within row, ${ }^{a} \mathrm{p}$ value by Fischer's exact test. 
therapy duration are as shown in table 5 and 6 respectively. Patients with CD4 count less than $300 \mathrm{cell} / \mathrm{mm}^{3}$ had significantly lower GLS value of less than $-18 \%$ compared with higher CD4 count ( $\mathrm{p}$ value of 0.05 ). However, there were no significant differences in GLS value with baseline HIV viral load, duration of HIV diagnosis, HAART therapy and its duration.

Intra-observer and inter-observer coefficients of variation were $<$ $10 \%$ in strain imaging echocardiography.

\section{Discussion}

HIV infection itself is accompanied by subclinical systolic dysfunction, not apparent to standard echocardiography that can be unmasked though using sensitive echocardiographic techniques. When present, early management of cardiovascular abnormalities in these patients may improve their well-being and survival. Currently, left ventricular ejection fraction is one of the most commonly used markers to evaluate LV systolic function, as assessed by conventional echocardiography ${ }^{1}$. However, this method has several limitations such as geometric assumptions, foreshortening, load dependency, interobserver variability, and the influence of the heart rate. Strain imaging (SI) has been able to detect subclinical myocardial dysfunction at an earlier stage compared with conventional imaging in a number of diseases ${ }^{11}$. This method has also been shown to evaluate LV systolic functions more comprehensively and reliably than conventional echocardiography methods ${ }^{12,13}$. It is an important marker to detect subclinical LVSD with a high sensitivity and specificity rate ${ }^{14}$. There are very few studies done evaluating GLS for detecting subclinical dysfunction in asymptomatic HIV patients.

The main analysis of the present study showed that asymptomatic HIV-infected patients without cardiovascular disease had significantly lower GLS value despite having normal LV systolic function compared to the that of healthy individuals which were similar to previous study done by Mendes et $\mathrm{al}^{15}$ and Cetin et $\mathrm{al}^{16}$. There were also very few study done with Doppler/TDI strain imaging and strain rate done by Sims A et $\mathrm{al}^{17}$, Onur et $\mathrm{a}^{18}$ and Karavidas et $\mathrm{al}^{19}$ which all have demonstrated impaired strain and strain rate despite having normal systolic function in HIV patients compared to the healthy control group.

Our study evaluate the relationship of LV function with GLS in HIV patients to baseline CD4 count, HIV viral Load, duration of HIV diagnosis, HAART therapy and HAART therapy duration showed patients with CD4 count less than $300 \mathrm{cell} / \mathrm{mm}^{3}$ had significantly lower GLS value less than $-18 \%$ compared with higher CD4 count. Previous study done by Onur et $\mathrm{a}^{18}$ and Karavidas et $\mathrm{al}^{19}$ found no relationship between CD4 T-cells and systolic strain. But later study done by Cetin et $\mathrm{al}^{16}$ showed positive correlation between reduced CD4 count and GLS value, though there were no significant difference between different CD4 level group below and greater than 300 .

There was no significant differences in conventional echocardiographic parameters between HIV population and healthy population except for transmittal E velocity ( $\mathrm{P}$ value of 0.001 ) which were significantly lower in the HIV group and this finding were similar to the study done by Karavidas et $\mathrm{al}^{19}$ and Mendes et $\mathrm{al}^{15}$. The diastolic function abnormalities such as reduced transmitral E velocity, an increased peak of A velocity, and an increased isovolumetric relaxation time and early filling duration has been described in HIV patients with wide variability in its incidence..$^{20,21}$ In our study only the reduced transmitral E velocity was found to be significantly lower probably because of impairment of LV contraction as detected with strain imaging, could precede the development of diastolic function abnormalities or smallsized study sample including only asymptomatic young HIV patients may have prevented us from reaching significant differences in other diastolic parameters.

The strength of the present Study was that our study population included 57\% female with larger sample size and younger age population compared to the previous study done by Karavidas et a ${ }^{19}$, Mendes et $\mathrm{al}^{15}$ and Cetin et $\mathrm{al}^{16}$. Our study had tried to overcome the limitation of previous study of underrepresented female population and less sample size.

\section{Limitation of the study}

The study was a descriptive cross-sectional study, CD4 T-cell counts were only measured in HIV-infected patients, but not in healthy individuals and indicators of myocardial fibrosis such as MRI imaging and biochemical variables as were unable to be investigated.

\section{Conclusion}

GLS imaging technique is a valuable tool for detecting subclinical LV dysfunction in asymptomatic HIV which is often overlooked by conventional echocardiography. It is likely that the subclinical LV dysfunction may later progress with higher incidence of cardiomyopathy and heart failure in HIV-infected patients. Thus, a low threshold for using these technique should be applied in asymptomatic HIV patients especially in patients with lower CD4 level for early detection of subclinical LV dysfunction. Although our study revealed that early subclinical dysfunction can be unmasked by GLS imaging, further large scale, long term follow up studies are needed to address the mechanisms involved in it and could also determine whether the reported low GLS value abnormalities would translate into a worse prognosis.

\section{Acknowledgment}

The author acknowledges the ART clinic team, Cardiology team of NAMS, Bir hospital.

\section{Conflict of interest: None}

\section{References}

1. Reinsch N, Kahlert P, Esser S et al. Echocardiographic findings and abnormalities in HIVinfected patients: Results from a large, prospective, multicenter HIV-heart study. Am J Cardiovasc Dis; 2011; 1:176-184. ISSN: 2160-200X/ AJCD1107001

2. Blaylock JM, Byers DK, Gibbs BT et al. Longitudinal assessment of cardiac diastolic function in HIV-infected patients. Int J STD AIDS; 2012; 23:105-110. https://doi.org/10.1258/ijsa.2011.011099

3. Lewis W. Cardiomyopathy in AIDS: a pathophysiological perspective. Prog Cardiovasc Dis 2000;43:151-170 https://doi.org/10.1053/pcad.2000.9031

4. Sani MU. Myocardial disease in human immunodeficiency virus (HIV) infection: a review. Wien K lin Wochenschr; 2008; $120: 77-87$. https://doi.org/10.1007/s00508-008-0935-3

5. Anderson DW, Virmani R. Emerging patterns of heart disease in human immunodeficiency virus infection. Hum Pathol 1990; 21:253-259. https://doi.org/10.1016/0046-8177(90)90224-S 
6. Barbaro G, Klatt EC. HIV infection and the cardiovascular system. AIDS Rev 2002;4:93-103.

DOI: 10.1345/aph.1D551

7. D'hooge J, Heimdal A, Jamal F et al Regional strain and strain rate measurements by cardiac ultrasound: principles, implementation and limitations. Eur J Echocardiogr; 2000; 1:154-170.

https://doi.org/10.1053/euje.2000.0031

8. Dandel M, Lehmkuhl H, Knosalla C et al. Strain and strain rate imaging by echocardiography - basic concepts and clinical applicability. Curr Cardiol Rev; 2009; 5:133-148. https://doi.org/10.2174/157340309788166642

9. Mor-Avi V, Lang RM, Badano LP et al. Current and evolving echocardiographic techniques for the quantitative evaluation of cardiac mechanics: ASE/EAE consensus statement on methodology and indications endorsed by the Japanese Society of Echocardiography. J Am Soc Echocardiogr; 2011; 24:277-313.

https://doi.org/10.1016/j.echo.2011.01.015

10. Collier P PD, Klein A, Testin A et al: Myocardial Strain Measured by Speckle-Tracking Echocardiography. JACC 2017; 69, 1043-1056.

https://doi.org/10.1016/j.jacc.2016.12.012

11. El-Menyar AA, Galzerano D, Asaad N et al: Detection of myocardial dysfunction in the presence of normal ejection fraction. J Cardiovasc Med; 2007; 8: 923-933. https://doi.org/10.2459/JCM.0b013e328014daf2

12. Nesbitt GC, Mankad S, Oh JK et al. Strain imaging in echocardiography: methods and clinical applications. Int J Cardiovasc Imaging; 2009; 25: 9-22.

https://doi.org/10.1007/s10554-008-9414-1

13. Kalam K, Otahal P, Marwick TH. et al Prognostic implications of global LV dysfunction: a systematic review and metaanalysis of global longitudinal strain and ejection fraction. Heart 2014; 100:1673- 1680. https://doi.org/10.1136/heartjnl-2014-305538
14. Roes SD, Mollema SA, Lamb HJ, et al. Validation of echocardiographic two-dimensional speckle tracking longitudinal strain imaging for viability assessment in patients with chronic ischemic left ventricular dysfunction and comparison with contrast-enhanced magnetic resonance imaging. Am J Cardiol 2009; 104: 312-317.

https://doi.org/10.1016/j.amjcard.2009.03.040

15. Mendes L, Silva D, Miranda C et al. Impact of HIV infection on cardiac deformation. Rev Port Cardiol 2014;33 :501-509. https://doi.org/10.1016/j.repc.2013.12.006

16. Cetin S, Gunduz A, Çetin S.A. et al. Evaluation of Subtle Left Ventricular Systolic Dysfunction by Longitudinal Systolic Strain in Patients with Human Immunodeficiency Virus. Acta Cardiol Sin 2018; 34:321- 327 doi: 10.6515/ACS.201807 34(4).20180222B

17. Sims A, Frank L, Cross R, et al. Abnormal cardiac strain in children and young adults with HIV acquired in early life. J Am Soc Echocardiogr 2012; 25:741-748. https://doi.org/10.1016/j.echo.2012.04.004

18. Onur I, Ikitimur B, Oz F, et al. Evaluation of Human Immunodeficiency Virus Infection Related Left Ventricular Systolic Dysfunction by Tissue Doppler Strain Echocardiography. Echocardiography 2014; 31: 1199-1204. https://doi.org/10.1111/echo.12569

19. Karavidas A, Xylomenos G, Matzaraki V. et al Myocardial deformation imaging unmasks subtle left ventricular systolic dysfunction in asymptomatic and treatment-naive HIV patients. Clin Res Cardiol; 2015; 104:975-981. https://doi.org/10.1007/s00392-015-0866-8

20. Martinez-Garcia T, Sobrino JM, Pujol E et al. Ventricular mass and diastolic function in patients infected by the human immunodeficiency virus. Heart 2000;84:620-4. https://doi.org/10.1136/heart.84.6.620

21. Goundray N, de Zuttere D, Force G, et al. Left ventricular diastolic function in asymptomatic and symptomatic human immunodeficiency virus carriers: an echocardiographic study. E ur Heart J 1995; 16:61-7. https://doi.org/10.1093/eurheartj/16.1.61 